\title{
Research on Discourse Right under the Environment of Network Ideological and Political Education
}

\author{
Meijun Ding ${ }^{1}$, Zhiqiang Mao', Wen Zheng ${ }^{1}$ \\ ${ }^{1}$ College of Marxism, Yunnan University of TCM, Kunming, Yunnan, 650500, China
}

Keywords: Emerging Media; Network Environment; University; Ideological and Political Education; Discourse Right

\begin{abstract}
The popularization of new media brings new opportunities and challenges to the ideological and political work, innovates the new paradigm of the discourse of ideological and political education in colleges and universities. It not only enriches the new content of the discourse of ideological and political education, but also impacts the mainstream ideology and values, and weakens the discourse power and control of ideological and political educators. To enhance the effectiveness of ideological and political education in colleges and universities, school ideological and political educators should keep pace with the times, occupy the network highlands of ideological and political education in colleges and universities, and make use of new media to change the discourse system of traditional ideological and political work. Based on the author's learning and practical experience, this paper first analyzed the characteristics of ideological and political education in colleges and universities under the network environment, and then discussed the new challenges to the discourse right of ideological and political education in colleges and universities under the network environment. Finally, the paper put forward the innovative strategies of the discourse right of ideological and political education under the network environment.
\end{abstract}

\section{Introduction}

In the new media era, the traditional media form has suffered a great blow, and the social discourse power has changed to a certain extent. Firstly, the traditional absolute right of speech held by the mainstream media has been gradually transferred to the new media represented by the self-media, and this trend is irreversible in the short term. Secondly, through the way of self-media, the speed and breadth of information dissemination have been greatly improved. Nowadays, the number of Internet users is increasing, and the popularization rate of the network has reached more than 50\%, and most netizens spend a certain amount of time using the network every day, which makes the self-media have the characteristics of wide audience. In a network environment, news events that have just taken place can spread to the entire network in a matter of minutes, which has a natural advantage over traditional media forms that are less efficient. To a certain extent, this has brought a new development prospect for ideological and political education in colleges and universities.

\section{The Characteristics of Ideological and Political Education in Colleges and Universities under the Network Environment}

\subsection{The tendency of decentralization of Communication subject}

With the rapid development of information technology and the popularization of multimedia information communication technology tools, the individual subject with communication will be able to carry out media communication within the legal definition. This extremely liberalized and open media environment magnifies the drawbacks of the traditional mainstream media, while the self-media with innovative content becomes the focus of public attention. Although the self-media has the extremely high social application value and creates the positive practical significance for the society, the traditional media center in the social level has been greatly reduced, as well as the 
university campus level thought influence. As a result, the ideological and moral consciousness of college students is negatively affected to a greater extent.

\subsection{Diversity and interactivity of communication modes}

Internet communication has the characteristics of diversity. It can be spread not only in the form of text, but also in the form of audio and video, pictures and so on, which makes the multimedia information content more interesting and concrete. The diversity of self-media communication can not only help information makers express their ideas more effectively and accurately, but also provide more comprehensible information content and more flexible reading options for information recipients. At the same time, the self-media communication mode has the interactive characteristic. Based on this feature, the self-media has significantly improved the quality of information exchange in people's life and work, and created a great space for information sharing in the fields of students' study, social economy production and so on.

\subsection{The disorder and virtualization of communication content}

Due to the wide range of multimedia audience, its information is also mostly life-based trivial content. At the same time, the network environment of our country has a very high degree of openness, which limits the content of self-media communication, so it may lead to the disordered information content of self-media platform. More than $96 \%$ of users in the liberalized self-media environment are anonymous users, which makes the information content in the self-media platform appear virtualized. Even some lawless elements and low moral quality users use the fictitious nature of the media to disseminate false information and content, which has a great negative impact on the social information environment and the ideological health of college students.

\section{New Challenges to the Discourse of Ideological and Political Education in Colleges and Universities under the Network Environment}

\subsection{The traditional discourse mode of ideological and political work needs to be renewed}

With the increasing acceptance of various network languages among college students, the traditional discourse of ideological and political education is gradually declining and facing severe challenges. In terms of form, the traditional discourse of ideological and political education needs to emphasize the function of political guidance. In terms of content, the traditional discourse of ideological and political education needs to highlight its political nature, lacking the breath of the times and life. At the same time, the traditional ideological and political education adopts monologue mode of language communication, showing a single subject type of discourse communication. In the era of mobile Internet, the new media display more flexible and diverse discourse forms, more colloquial, life and ridicule, and a variety of new words to the traditional ideological and political education discourse changes put forward new requirements of the times.

\subsection{Impact on the mainstream values of socialism}

The open society and convenient network make the cultural view and values of Chinese society colorful and pluralistic. Just as a coin has two sides, while enjoying the convenience of the Internet, college students will also encounter the bad ideological influence of the mud and sand, and the traditional socialist mainstream ideology and the mainstream values will be greatly impacted. At the same time, the dissubjectivity of network communication, the unconsciousness of groups and the polarization of public opinion also bring great influence to the ideological values of college students. At present, the values such as free nationalism, historical nihilism, money supremacy and so on, which spread among the group of young college students, make the college students' outlook on life, world outlook and values go further and further away from the mainstream socialist values.

\subsection{The authority of traditional ideological and political educators is weakened}

In the traditional media, communicators and educators always occupy the right to speak. However, in the new media era, by a small network line, a smart phone, everyone can form their 
own media, so college students are both the audience and the protagonist of communication. In the new media environment, the subject of communication is gradually dispelling, and the authority of traditional ideological and political educators is gradually weakened. The intermingled network information will bring impact to the ideological and political education work in the new era, and weaken the ideological control power of the ideological and political education workers to the college students.

\section{The Innovative Strategies of the Discourse Right of ideological and Political Education in Colleges and Universities under the Network Environment}

\subsection{Ideological and political work in Colleges and Universities needs to change from monologue to dialogue under the under the network environment}

In the new media era, the reconstruction of educational discourse mode of ideological and political work must change from the traditional monologue language system to the dialogue mode of equal communication. The arrival of the new media era has expanded the working space of ideological and political education in colleges and universities, and provided a new paradigm for ideological and political education in colleges and universities. Therefore, it needs the ideological and political workers in colleges and universities to start from creating equal and harmonious dialogue and exchange space, taking the ideological characteristics and realistic demands of contemporary college students as the starting point, and fully arousing the subjective initiative of college students to participate in the dialogue of ideological and political education, to build self-media communication platform, master the vocabulary commonly used by students in the media era, and narrow the psychological distance between students and them.

\subsection{The ideological and political work in Colleges and Universities needs to be combined with reality under the network environment}

Different from the traditional ideological and political education, the ideological and political workers in colleges and universities in the new media era should fully realize that the Internet is an invisible but real virtual space. Through the new way such as mobile Internet, the actual effect of ideological and political work in colleges and universities is improved by the combination of virtual and practical work mode. As Xi Jinping has said: in order to seize the new highlands of online education, ideological and political educators in colleges and universities should and must make good use of the propaganda positions under the new media forms such as Weibo, WeChat, and the public number platform. Propagate socialist positive energy and social mainstream values in the form that students like to see, and do a good job in guiding public opinion. At the same time, the ideological and political educators in colleges and universities should realize that the virtual new media space is an effective platform to expand the ideological and political education in colleges and universities, but the ideological and political work in colleges and universities must not only rely on the virtual space of new media. We also need to combine the ideological and political education with reality, through equal dialogue with students, exchange of heart-to-heart, campus activities, community construction and other ways, care about the growth of students, so that the ideological and political education work in colleges and universities to achieve a combination of reality. So that the ideological and political education in colleges and universities can be effectively demonstrated.

\subsection{The ideological and political work in Colleges and Universities needs to return to the life world from the academic world under the network environment}

As a form of ideological representation and dissemination, ideological and political work in colleges and universities is often marked by political science and likes to describe the characteristics of the world statically and abstractly with a grand and abstract academic tone. This gradually formed an abstract dogmatic form of expression, neglected the daily life of the microcosm, obscured the personality characteristics and value demands of college students, and eventually led 
to the gradual alienation of ideological and political education work from the real world in colleges and universities. In the face of the characteristics of media communication in the new media age, the ideological and political discourse system in colleges and universities should and must return to the world of life from the academic world. This paper combines the usual theoretical description tone of the academic world with the practical activities in the world of life, and describes the political implication in a tone full of life. In order to return to life, the ideological and political work in colleges and universities should first of all come into the world of students, stand in the perspective of students, look at the problems in life from the perspective of students, and take high respect for the life world of college students as the foundation. On the basis of careful reflection on the real world, taking the events in the real life of college students as the material, turning abstract political macroscopical words into popular, living sentences, and taking the origin of life as the basis, to realize the rational return of the discourse value of ideological and political education in colleges and universities.

\section{Summary}

In the new media era, if we want to innovate the discourse system of ideological and political education in colleges and universities under the new media environment. It requires ideological and political workers in colleges and universities to move from monologue to dialogue, and to improve the effectiveness of ideological and political education through the combination of reality and vanity. Also, it needs to return to the world of life from the academic world, combine the theoretical descriptive tone used in the academic world with the actual activities in the world of life, and describe the political implication in a tone full of life, to make the discourse right of ideological and political education in colleges and universities share elegance and vulgarity, and finally improve the effectiveness of ideological and political education in colleges and universities.

\section{References}

[1] Xiao Lu, Jin Jun. A study on the Reconstruction of discourse right of ideological and political Education in Colleges and Universities under the Environment of Media [J]. Journal of Heihe University, 2018, 9(03): 46-47.

[2] Liang Wenwen. A study on strengthening the discourse right of ideological and political Education in Colleges and Universities under the New Media Environment [J]. Heihe Journal, 2018, (02): 116-117.

[3] Gu Zhao, Yuan Limei, ancestor Qinghai. The Choice of the way to reshape the discourse right of ideological and political Education under the Environment of Media [J]. The World of Labor Security, 2018, (08): 76.

[4] Xiong Yani. Construction of discourse right of ideological and political Education in Colleges and Universities under Network Environment [J]. Journal of Shengli Oil Field Party School, 2017, 30(06): 109-113.

[5] Hu Yuning, Xue Yunyun. Transformation and shaping of discourse right of ideological and political Education in Colleges and Universities under the Environment of Media Communication [J]. Ideological Education Research, 2017, (09): 105-108. 